University of Wollongong

Research Online

Faculty of Business - Papers (Archive)

Faculty of Business and Law

$1-1-2017$

\title{
The Effect of Board Diversity on Earnings Quality: An Empirical Study of Listed Firms in Vietnam
}

Trang Cam Hoang

Ton Duc Thang University, tch855@uowmail.edu.au

Indra Abeysekera

Central Queensland University, indraa@uow.edu.au

Shiguang Ma

University of Wollongong, shiguang@uow.edu.au

Follow this and additional works at: https://ro.uow.edu.au/buspapers

Part of the Business Commons

Research Online is the open access institutional repository for the University of Wollongong. For further information contact the UOW Library: research-pubs@uow.edu.au 


\title{
The Effect of Board Diversity on Earnings Quality: An Empirical Study of Listed Firms in Vietnam
}

\author{
Abstract \\ Previous studies have established that firms' effectiveness can differ based on the differences among \\ directors within a board, and between boards. However, studies have yet to establish the effectiveness of \\ the diverse attributes of the board on firms' quality of earnings in an emerging market setting such as \\ Vietnam. This study investigates the effect of board diversity on earnings quality in a sample of \\ Vietnamese listed firms. The two dimensions of board diversity measures in this study cover a wide range \\ of structural and demographic attributes of board of directors, using a diversity-of-boards index \\ (dissimilarities among firm boards, i.e., board structure) and a diversity-in-boards index (dissimilarities \\ among directors within a board, i.e., demographic attributes of board members). Earnings quality is an \\ aggregate measure compiled from four accounting-based measures of earnings quality: accruals quality, \\ earnings persistence, earnings predictability and earnings smoothness. We find a significant, positive \\ linear relationship between diversity of boards and earnings quality, while the relationship between \\ diversity in boards and earnings quality is non-linear, with a U-shaped curve.

\section{Disciplines \\ Business}

\section{Publication Details} \\ Hoang, T., Abeysekera, I. \& Ma, S. (2017). The Effect of Board Diversity on Earnings Quality: An Empirical \\ Study of Listed Firms in Vietnam. Australian Accounting Review, 27 (2), 146-163.
}




\title{
The Effect of Board Diversity on Earnings
}

\section{Quality: An Empirical Study of Listed Firms in}

\section{Vietnam}

\author{
Trang C. Hoang ${ }^{1}$, Indra Abeysekera ${ }^{2, *}$, and Shiguang $\mathrm{Ma}^{3}$ \\ ${ }^{1}$ Faculty of Accounting, Ton Duc Thang University, Ho Chi Minh city, \\ Vietnam; hoangcamtrang@tdt.edu.au \\ ${ }^{2,{ }^{*}}$ S P Jain School of Global Management, Sydney, Australia \\ indraabeysekera@gamil.com \\ ${ }^{3}$ School of Accounting, Economics and Finance, University of Wollongong, \\ Australia.shiguang@uow.edu.au
}

\begin{abstract}
Previous studies have established that firms' effectiveness can differ based on the differences among directors within a board, and between boards. However, studies have yet to establish the effectiveness of the diverse attributes of the board on firms' quality of earnings in an emerging market setting such as Vietnam. This study investigates the effect of board diversity on earnings quality in a sample of Vietnamese listed firms. The two dimensions of board diversity measures in this study cover a wide range of structural and demographic attributes of board of directors, using a diversity-of-boards index (dissimilarities among firm boards, i.e., board structure) and a diversity-inboards index (dissimilarities among directors within a board, i.e., demographic attributes of board members). Earnings quality is an aggregate measure compiled from four accounting-based measures of earnings quality: accruals
\end{abstract}


quality, earnings persistence, earnings predictability, and earnings smoothness. We find a significant and positive relationship between diversity-of-boards and earnings quality; while the relationship between diversity-in-boards and earnings quality represents a non-linear U-shaped curve.

Key words: board of directors, diversity-of-boards, diversityin-boards, earnings quality, Vietnam.

JEL classification: G3, M1, M4, J1

\section{Summary at a glance}

This study investigates the impact of board diversity and earnings quality with a sample of Vietnamese listed firms. We find a significant and positive relationship between diversityof-boards (dissimilarities among firm boards) and earnings quality; while the relationship between diversity-in-boards (dissimilarities among directors within a board) and earnings quality represents a non-linear U-shaped curve. 


\section{Introduction}

The board of directors forms one of the cornerstones of corporate frameworks. The organization, structure, quality and operation of the board of directors determine many aspects of a firm. Several scholars have examined the implications of board diversity in relation to organizational outcomes, although the meaning of board diversity has not been explicitly defined (Harrison and Klein 2007). Most of the literature examines the individual attributes of the demographic diversity among directors within a board (such as gender diversity, age diversity, nationality diversity) and/or the structural attributes of board of directors, such as the chairperson also being the Chief Executive Officer (CEO), board independence, director ownership in relation to organizational outcomes, rather than their combined attributes. A few studies have attempted to combine the demographic or structural dimensions of board of directors into a single examination to formulate a complete picture of demographic as well as structural diversity (see BenAmar et al. 2013; Hafsi and Turgut 2013).

This paper employs two dimensions of board diversity (Hafsi and Turgut 2013) to investigate the impact of board diversity on the earnings quality of Vietnamese listed firms. The two dimensions of board diversity are measured by a diversity-of-boards index (dissimilarities among firm boards, a dimension which relates to board structure) and a diversity-in- 
boards index (dissimilarities among directors within a board, which relates to demographic attributes of board members). However, we extend Hafsi and Turgut's (2013) indices in two ways. First, we use a refined measure of variables about diversity-in-boards and diversity-of-boards applicable to Vietnam, an emerging market. Prior researchers have concluded that governance structures are likely to develop endogenously, depending on specific characteristics of the firm and the unique business environment in a particular country (Demirguc-Kunt et al. 2006; Haniffa and Hudaib 2006).

Second, unlike Hafsi and Turgut (2013), who combined several attributes into a single index with equal weights to construct diversity-of-boards and diversity-in-boards indices, which may produce unexpected drawbacks (Ben-Amar et al. 2013), we apply both weighted and unweighted methods to measure diversity-in-boards and diversity-of-boards indices. A survey questionnaire provides executives' perceptions about various attributes relating to board diversity to determine their importance. A comparison of our results between weighted and unweighted methods allows us to investigate the potential impact of the perceived importance of attributes relating to the diversity-in-boards and diversity-of-boards and their impact on earnings quality.

\section{Theoretical framework and hypothesis}

\section{development}




\section{Theoretical framework}

Board diversity is presented as both fiduciary and advisory in nature (Ben-Amar et al. 2013; Labelle et al. 2010). Both roles may affect the quality of earnings in different manners. From the fiduciary perspective, board of directors have to be less dependent on each other and even specialists in monitoring shareholders' interests. This is as stipulated in the current regulation and generally accepted governance principles. Agency theory (Jensen and Meckling 1976) predicts management interests are different and even in conflict with those of shareholders. According to the agency theory, diversity-of-boards can be used to establish better monitoring and control mechanisms. It is based on the assumption that directors with their own sets of rationalities can contribute with different styles of controlling and monitoring the management appropriate to the firm. The diverse fiduciary perspectives resulting from the board members can become effective in developing a sound controlling and monitoring mechanism. Therefore, it is argued here that the diversity-of-boards directly contributes to increasing the earnings quality of firms.

From the advisory perspective of governance, board effectiveness requires a diversity of knowledge, competencies, and organizational values to guide and contribute to organizational learning and strategic decision making. The emphasis here is on counselling and mentoring the 
management, and not on the statutory characteristics such as the diversity of interests or the financial literacy of the directors. The idea that board diversity affects firm performance has roots in resource dependence theory (Pfeffer and Salancik 1978). Resource dependence theorists have specifically argued that the combining diverse stakeholder perspectives in board decision-making, improves firms' ability to obtain resources critical to their functioning (Davis and Cobb 2010; Pfeffer 1973). Diversity is necessary for board members to be able to ask knowledgeable questions to shape the managerial decision-making process and the organizational culture. According to Reidenbach and Robin (1991), the moral development of a firm is determined by the firm's culture and in a reciprocal fashion. By questioning, criticizing, advising, and counselling, diversity-in-board enhances the degree of moral or ethical development of a firm (Labelle et al. 2010), and thus is likely to improve the earnings quality of a firm.

Hypotheses development

Diversity-of-boards and earnings quality.

A large body of literature has examined the relationship between structural attributes of board of directors relating to the diversity-of-boards and earnings quality (Klein 2002; Park and Shin 2004; Rahman and Ali 2006). These structural attributes are identified to represent recommended 'best practice' governance. However, most of the literature focuses on specific 
attributes, rather than their combined attributes, and the findings from those studies are inconclusive.

In this study, diversity-of-boards is an index-driven variable based on four structural attributes of board of directors: $\mathrm{CEO} /$ chair separation, non-executive directors ${ }^{1}$ owning more than five per cent of a firm's equity (blockholders), representative directors' ownership and promoters. The term 'representative directors' refers to a director representing the interest of the appointing party (such as government). We examined the role of representative directors in the board of directors because 97 of the firms in the sample (representing $65 \%$ ) had representative directors.

(i) CEO/chair separation. The Code of Corporate Governance in Vietnam mandates the separation of the role of chairperson of the board of directors and CEO in a listed firm. However, a person occupying a dual role is allowed if shareholders approve it at general meetings. The separation of the board's CEO and chairperson results in reduced agency problems because it allows more independence of the board from management for decision making (Donaldson and Davis 1991; Jackling and Johl 2009; Jensen 1993). Prior studies suggest that the separation of chairperson from $\mathrm{CEO}$ is an important element in preventing earnings management (Rahman and Ali 2006; Robert et al. 2008). 
(ii) Non-executive directors owning more than five per cent of a firm's equity (blockholders). Prior research suggests that nonexecutive directors who also hold blocks of shares in a firm can reduce agency costs (Agrawal and Nasser 2011, 2012). A board seat provides the monitoring function over managers, and the block shareholdings provide ownership interest. This combination can produce a greater propensity to align managerial self-interests with shareholder self-interests. Thus, a non-executive director who is also a blockholder can play a more forceful governance role (Agrawal and Nasser 2012). From an agency point of view, board members are assumed to be more alert if they have equity involvement (Sonnenfeld 2002).

(iii) Representative directors' ownership. Most Vietnamese listed firms have been transformed from traditional state-owned enterprises (SOEs) into listed status, but the ownership of these firms is still heavily concentrated in the hands of large stateowned shareholders ( $\mathrm{Vu}$ et al. 2011). Instead of having government bureaucrats directly supervising the SOEs as before, the state now formally exercises its rights as a major shareholder by appointing representative directors to boards. From an agency theory perspective, directors' level of shareholding, both of individual and representative stocks, is seen as an incentive to reduce agency costs. 
(iv) Promoters. Following Jayati, Subrata and Kaustav (2008), we define promoters as controlling shareholders (i.e., the government in our study) who also serve as inside directors on the board. In India, family-owned corporations are common (Jayati et al. 2008); while the Vietnamese government still retains a substantial amount of ownership in many listed firms, especially those deemed to be large and strategically important to the nation (Carlin and Pham 2009). In order to monitor these listed firms, the government appoints representatives on the board of directors. Previous studies have shown that the protection of state-owned listed firms by the government reduces the incentives for managers to manipulate firm-specific information (Ding et al. 2007; Wang and Yung 2011). In Vietnam, outside directors may serve as representative directors for the government to carry out its duty, but this is relatively ineffective compared to inside directors who also serve as representative directors for government (Representative News, 2012). This is because the outside directors of many firms know little of the firms they represent; hence they fail to fulfill their role. Previous studies also show that it can be good to have a number of inside directors on the board as they may be very candid and well-informed (Baysinger and Butler 1985; Sonnenfeld 2002). Agency theory states that a firm's top management becomes more powerful when the board of 
directors is composed of people who know little of the firm (Mulili and Wong 2011).

Combining the structural characteristics of board of directors relating to diversity between boards into a composite measure gives a comprehensive picture of their simultaneous influence on various organizational outcomes (Ben-Amar et al. 2013; Hafsi and Turgut 2013). Based on the propositions of the agency theory, structural attributes of the board of directors are designed to control agency conflict by demanding more conservatism. Directors are then likely to know early about any future losses. Such early information allows directors to control managers' opportunistic behaviour. Based on this discussion, this states the first hypothesis as follows.

H1: Diversity-of-boards improves earnings quality.

Diversity-in-boards and earnings quality. Earlier studies have analyzed the relationship between demographic diversity among directors and organizational financial performance, rather than earnings quality, and the published evidence remains focused on developed economies (Mahadeo et al. 2012).

In this study diversity-in-boards is an index-driven variable based on the following four attributes of directors sourced from the literature: gender, age, education degree and nationality. These are among several other demographic attributes examined in the literature, and are often mentioned in isolation 
but rarely together (Erhardt et al. 2003; Kang et al. 2007; Post et al. 2011).

(i) Director gender. The main board diversity characteristic in the examined prior studies is gender diversity. Recently, researchers have begun to examine the relationship between gender diversity and earnings quality, and they document that the presence of women on the boards leads to better board dynamics and improved reported earnings quality (Adams and Ferreira 2009; Francis et al. 2009; Srinidhi et al. 2011). However, these findings focus on the US. Meanwhile, Ye, Zhang and Rezaee's (2010) study in China as well as Hili and Affes's (2012) study in France do not show a significant relationship.

(ii) Director age. Directors' age reflects their business experience and is evidence of their maturity in company management (Kang et al. 2007). Prior studies point out that older members exhibit more conservative and moral judgment (Hambrick and Mason 1984; McCabe et al. 2006). Due to the greater conservatism of older members, it is expected that boards with older directors will have higher reported earnings quality. However, this tendency is changing, and there is an active promotion of age diversity in order to encourage the varying perspectives of different age groups, and as an integral part of succession planning (Kang et al. 2007; Mahadeo et al. 2012). 
(iii) Director education degree. Director education degree is viewed as an indicator of directors' knowledge, cognitive orientation and skill base (Hambrick and Mason 1984). Previous research documents that a high level of education among directors on boards results in a greater ability to adopt new ideas, accept innovations (Guthrie et al. 1991; Wally and Baum 1994) and offers a broader view and larger breadth of understanding (Post et al. 2011). More diverse boards possess more diverse knowledge bases, as well as the perspectives necessary to develop and evaluate solutions to complex problems (Milliken and Martins 1996; Van der Walt et al. 2006).

(iv) Director nationality. With increasing globalization, firms tend to modify their governance structures by having more foreigners on their boards (Carpenter 1998; Oxelheim et al. 2013). Milliken and Martins (1996) suggest that diversity in national background may have a negative influence on process effectiveness and performance in the beginning, but after a while, more efficient processes and higher performance seem to occur. Vietnam's reform policy from 1986 incorporated trade liberalization for direct foreign investment and provided incentives to attract more foreign investment. Heijltjes, Olie and Glunk (2003) suggest that if the home country is small, there is a need to grow internationally, and thus the board 
should be international as well. Being a small and new emerging country, Vietnam is a good case study.

Directors' heterogeneous attributes are likely to bring in different perspectives for discussion and making decisions of the board. The propositions of the resource dependence theory suggest that increased questioning, criticizing, advising, and counselling, associated with diversity-in-board can enhance the degree of moral or ethical development of a firm (Labelle et al. 2010). Based on the preceding discussion of the existing literature and resource dependence theory, the second hypothesis is stated as follows.

H2: Diversity-in-boards improves earnings quality.

\section{Research methods}

\section{The sample}

Our sample consists of all Vietnamese listed firms for which the required data items are available, except for those in banks and financial institutions because their financial statements are prepared in accordance with their special regulatory environment.

This study measures individual earnings quality using 5-year rolling windows ${ }^{2}$ from 2006 to 2010 to generate the 2010 earnings quality measures of the sample, similar to Francis et al. (2008). Accruals quality is one of four earnings quality measures in this study. Due to estimating this measure requires lagged and forward data, it generates the 2010 earnings 
attributes measures of the sample by using the financial statement data items for seven years from the fiscal years 2005 to 2011 .

The financial statement data items were extracted by hand from Ho Chi Minh stock exchange (HOSE)'s website (www.hsx.vn) and Hanoi stock exchange (HNX)'s website (www.hnx.vn) because there were no electronic databases of financial, statistical and market information on Vietnamese listed firms. To include in the sample, each firm must have an income statement, balance sheet, and cash flow statement for all seven fiscal years. This is a perfectly balanced panel with each firm having the same number of observations.

The raw data for calculation of board diversity indices in this study is hand-collected from the 2010 annual reports and firm websites. Our final sample, with all required data available, includes 150 firms.

\section{Earnings quality measures}

The literature widely uses two types of earnings quality measure: accounting-based measures and market-based measures. A fundamental assumption underlying the marketbased measure is that the markets efficiently incorporate accounting information. We choose accounting-based measures because the Vietnamese market is new and semi-efficient (Phan and Zhou 2014; Truong et al. 2008). Additionally, managers are likely to manipulate accounting-based measures, while it is 
much harder to manipulate market-based measures (Prior et al. 2008).

This study constructs a standardised aggregate earnings quality score as a proxy for earnings quality in the main analyses ${ }^{3}$, based on four accounting measures which have been used in prior studies (Boonlert-U-Thai et al. 2006; Francis et al. 2004). They are accruals quality, earnings persistence, earnings predictability and earnings smoothness. Prior studies have used a standardised aggregate earnings quality/management score as a proxy for earnings quality/management (see Gaio and Raposo 2011; Leuz et al. 2003). Additionally, factor analysis suggests that a single standardised aggregate measure of earnings quality which represents four earnings attribute measures in this study is valid (more details of factor analysis is in Findings Section). Accruals quality. Accruals quality (AQ) in this study is based on the widely used Dechow and Dichev (2002) statistical calculation technique, where it is measured by relating total current accruals to cash flows from operations. AQ is the standard deviation of residuals $\left(\varepsilon_{\mathrm{j}}\right)$ from the following regression:

$\mathrm{TCA}_{\mathrm{j}, \mathrm{t}}=\varphi_{0}+\varphi_{1} \mathrm{CFO}_{\mathrm{j}, \mathrm{t}-1}+\varphi_{2} \mathrm{CFO}_{\mathrm{j}, \mathrm{t}}+\varphi_{3} \mathrm{CFO}_{\mathrm{j}, \mathrm{t}+1}+\varepsilon_{\mathrm{j}, \mathrm{t}}$

Where $\mathrm{TCA}_{\mathrm{j}, \mathrm{t}}=$ firm $\mathrm{j}$ 's total current accruals in year $\mathrm{t}\left(\Delta \mathrm{CA} \mathrm{A}_{\mathrm{j}, \mathrm{t}}\right.$ $\left.\Delta \mathrm{CL}_{\mathrm{j}, \mathrm{t}}-\Delta \operatorname{Cash}_{\mathrm{j}, \mathrm{t}}+\Delta \mathrm{STDEBT}_{\mathrm{j}, \mathrm{t}}\right) ; \mathrm{CFO}_{\mathrm{j}, \mathrm{t}}=$ firm j's cash flow from operations in year $\mathrm{t} ; \Delta \mathrm{CA}_{\mathrm{j}, \mathrm{t}}=$ firm $\mathrm{j}$ 's change in current assets between year $\mathrm{t}-1$ and year $\mathrm{t} ; \Delta \mathrm{CL}_{\mathrm{j}, \mathrm{t}}=$ firm $\mathrm{j}$ 's change in 
current liabilities between year $\mathrm{t}-1$ and year $\mathrm{t} ; \Delta \mathrm{Cash}_{\mathrm{j}, \mathrm{t}}=$ firm j's change in cash between year $\mathrm{t}-1$ and year $\mathrm{t}$; and $\triangle \mathrm{STDEBT}_{\mathrm{j}, \mathrm{t}}$ $=$ firm $\mathrm{j}$ 's change in debt in current liabilities between year $\mathrm{t}-1$ and year t. All variables in equation (1) are deflated by firm j's total assets in year t-1. Larger values of AQ indicate less earnings quality.

Earnings Persistence. Earnings persistence (PERSIS) is the extent to which current period earnings reflect future period earnings. We follow Francis et al. (2004) and measure PERSIS as the negative of the slope coefficient estimate, $\phi_{1, j}$, from the following model:

$\operatorname{Earn}_{\mathrm{j}, \mathrm{t}}=\phi_{0, \mathrm{j}}+\phi_{1, \mathrm{j}} \operatorname{Earn}_{\mathrm{j}, \mathrm{t}-1}+\mathrm{v}_{\mathrm{j}, \mathrm{t}}$

Where $\operatorname{Earn}_{\mathrm{j}, \mathrm{t}}=$ firm's j net income before extraordinary items in year t. All variables in equation (2) are deflated by firm j's total assets in year t-1. Larger values (i.e., less negative) of PERSIS indicate less earnings quality.

Earnings predictability. Earnings predictability (PREDICT) is the ability of earnings to predict itself (Lipe 1990). Our measure of PREDICT is the standard deviation of the residuals $\left(v_{j}\right)$ from equation (2), following Francis et al. (2004). Larger values of PREDICT imply less earnings quality.

Earnings smoothness. This study adopts the measure of earnings smoothness (SMOOTH) in Francis et al. (2004) as the ratio of firm i's standard deviation of net income before extraordinary items scaled by beginning total assets, to its 
standard deviation of cash flows from operations scaled by beginning total assets. Larger values of SMOOTH imply less earnings quality.

The aggregate earnings quality score. Based on the four individual earnings quality measures (AQ, PERSIS, PREDICT, SMOOTH), we construct a standardised aggregate earnings quality score and use it to draw the conclusion of the impact of board diversity on earnings quality. The larger the value of the individual earnings quality measure, the lower the earnings quality. Following Leuz, Nanda and Wysocki (2003), we rank the four individual earnings quality values in descending order, so that a higher ranked value now represents higher earnings quality. The standardised aggregate earnings quality score of a firm is computed by averaging the firm rankings for the four individual earnings quality measures.

\section{Board diversity measures}

Four board diversity indices are constructed in this study to measure board diversity: unweighted diversity-of-boards index (UW_DoB), unweighted diversity-in-boards index (UW_DiB), weighted diversity-of-boards index (W_DoB) and weighted diversity-in-boards index (W_DiB).

Unweighted diversity-of-boards index. As noted earlier, we include four structural attributes of board of directors to construct the diversity-of-boards indices. These are measured as shown in Table 1. 
< Insert Table 1 about here>

In order to construct UW_DoB, we use the inter-sample distance-measurement method (Hafsi and Turgut 2013) which measures the structural dissimilarity among firm boards. This method shows the degree of dissimilarity of all four structural attributes of board of directors in a given firm board, from those in other firm boards in the sample. We construct a matrix by first measuring the dissimilarity between a given firm and another firm in regard to all structural attributes of board of directors (i.e., four attributes in this study) simultaneously. Next, we measure such dissimilarity for all other firms. Then, we take the average of the dissimilarity between a given firm and the remaining firms in the sample as UW_DoB of the given firm. Similarly, we measure UW_DoB for other firms. Consequently, we discovered how dissimilar (or diverse) a firm is from the remaining firms in the sample.

Because the data types of structural attributes of a board of directors in this study are different (i.e., binary and ratio scale types), following Han and Kamber (2006), we applied a new approach to process all different data types together. The technique combines the different attributes into a single dissimilarity matrix, bringing all attributes of interest onto a common scale of the interval $[0,1]$. A higher scale represents higher diversity-of-boards. The details of this method are in the Appendix. 
Unweighted diversity-in-boards indices. Table 1 describes the measurement of four demographic attributes of board of directors in detail. Because the intent here is to measure how diverse demographic attributes are within a board (gender, age, education degree and nationality), each of these attributes is measured using the modified Blau's index (1977). This index has been suggested as an optimal measure of diversity to capture variations within a group of people (Harrison and Klein 2007).

Director age is classified into six subgroupings: under 36 years, 36-45, 46-55, 56-65, 66-75 and over 76, following Mahadeo, Soobaroyen and Hanuman (2012). We choose this classification because Mahadeo et al.'s (2012) study also examines an emerging economy (Mauritius). Because there is no directors over 76 in our sample firms, this subgrouping is dropped from the classification of director age.

After identifying classifications within each of these demographic attributes, we employed Blau's index to measure how diverse were the four attributes within a board above. Blau's index was calculated by the following formula:

$$
1-\sum\left(p_{k}^{2}\right)
$$

Where variety can take $\mathrm{k}=1, \ldots, \mathrm{K}$ possible categories, and $\mathrm{p}$ represents the proportion of members of board of directors in the $\mathrm{k}^{\text {th }}$ category. When Blau's index gains a large value, diversity-in-boards increases. However, in order to get a 
standardised range from zero to unity for all demographic diversity attributes, we use the method introduced by Agresti and Agresti (1978). This method multiplies Blau's index by $\mathrm{K} /(\mathrm{K}-1)$, called the modified Blau's index. Then, to construct the UW_DiB, we split the sample into terciles for each attribute to rank diversity levels (Ben-Amar et al. 2013; Hafsi and Turgut 2013). These groups then take values of zero for the first tercile, one for the second and two for the third. Finally, UW_DiB is the sum of all ranked attributes that are involved in demographic diversity within a board for each firm. A higher value represents higher diversity-in-boards.

Weighted diversity-of-boards and weighted diversity-in-boards indices. We construct $\mathrm{W} \_$DoB and W_DiB similar to UW_DoB and UW_DiB, but each attribute of board of directors is weighted based on executives' perceptions to weigh their importance (Dess and Davis 1984). Specifically, we conduct a survey to examine executives' perceptions of the relevance of board of directors' attributes on earnings quality of Vietnamese listed firms. ${ }^{4}$ Corporate executives of Vietnamese listed firms experientially know the mindset of the board of directors towards the quality of earnings; hence we request that executives assign weighting to each attribute of board of directors which impacts on earnings quality of Vietnamese listed firms. Each attribute is assigned a weight ranging from 0 (unimportant) to 10 (most important). This wide scale increase 
the variance obtained and to make the results more reliable (Hartley and Betts 2010). The questionnaire was sent to 150 executives of all the firms in the sample. A total of 80 usable replies were received which represented a response rate of $53.33 \%$.

In order to measure W_DoB, we calculate $\delta_{i j}^{(f)}$ in Equation (7) (see the Appendix) with each attribute to construct the diversity-of-boards index of each firm by the following formula:

$$
\delta_{i j}^{(f)}=\frac{p^{*} \text { MEANRATING }_{f}}{\sum_{f=1}^{p} \text { MEANRATING }_{f}}
$$

where $\delta_{i j}^{(f)}$ is the indicator of attributes $\mathrm{f}$ weighted; $\mathrm{p}$ is the number of attributes $\mathrm{f}$; and MEANRATING is the mean importance rating of each attribute $f$. Then we use equation (7) with $\delta_{i j}^{(f)}$ modified to measure W_DoB of each firm board.

Turning to W_DiB, based on the mean importance rating of each attribute from the questionnaire survey, we calculated W_DiB as the sum of all the ranked attributes (out of four) used to construct the diversity-in-boards index in this study, with each ranked attribute being a multiple of its mean importance rating. A higher value represents higher diversity-in-boards.

Control variables. We control for several variables that are described as 'innate determinants' in prior research where they are found to be related to earnings quality (Francis et al. 2005). These control variables are referred to as innate determinants 
because they are less likely to change in the short run. They include firm size (SIZE), length of operating cycle (LOG.OC), cash flow variability (STD.CFO), sales variability (STD.SALES), and incidence of net loss realizations (LOSS). All variables are measured over rolling five-year periods, consistent with the measures of earnings quality. SIZE is computed as log of the firm's average total assets. LOG.OC is measured as the $\log$ of the sum of the firm's days account receivable and days inventory. STD.CFO is calculated as the standard deviation of the firm's cash flows from operations, scaled by total assets. STD.SALES is measured as the standard deviation of the firm's sales revenues, scaled by total assets. LOSS is computed as the number of years where the firm reported loss over previous five years. Because the government still holds a large proportion of ownership in many Vietnamese listed firms (Vu et al. 2011) and studies using the sample in China (Ding et al. 2007; Wang and Yung 2011) show that state ownership is related to earnings quality, we also use the state ownership (STATE), measured by the percentage of shareholding owned by the state, as a control variable in this study.

\section{The impact of board diversity on earnings quality}

We tested hypotheses 1 and 2 regarding the effects of board diversity on earnings quality, using an ordinary least squares (OLS) estimator. The regression functions are: 
$E Q_{i}=\alpha_{0}+\alpha_{1} D o B_{i}+\sum \gamma_{j, i}$ control variables ${ }_{i}+\varepsilon_{i}$

$E Q_{i}=\beta_{0}+\beta_{1} D_{i B}+\Sigma \eta_{j, i}$ control variables $_{i}+\varepsilon_{i}$

where $\mathrm{EQ}_{\mathrm{i}}=$ firm i's the stadardised aggregate earnings quality score, calculated as the average rank across the four individual measures (AQ, PERSIS, PREDICT, SMOOTH); DoB $_{\mathrm{i}}=$ firm i's indices (unweighted and weighted) of diversity-of-boards; $\mathrm{DiB}_{\mathrm{i}}=$ firm i's indies (unweighted and weighted) of diversityin-boards.

\section{Findings}

\section{Descriptive statistics}

Table 2 shows a statistical description of the mean score of 80 executives' perception about attributes. The scores vary between 4.3 and 8.5 within a possible score range between zero and 10. Respondents considered the Promoters attribute (i.e., the percentage of executive directors who also serve as representative directors on the board) as the most important board of directors attribute towards maintaining firms earnings quality. Its mean score was 8.5. Respondents considered other structural attributes of board of directors were also important. Their responses show that structural attributes are more important than the demographic attributes of board of directors in the relationship with earnings quality. Among the demographic attributes, respondents rated the directors' gender as the least important, with a mean of 4.3 .

< Insert Table 2 about here> 
Table 3 presents the descriptive statistics. The sample mean value of EQ is 75.5. A higher EQ implies a higher level of earnings quality. The AQ measure has a mean value of 0.06 . As a benchmark, Boonlert-U-Thai et al. (2006) report mean values of 0.065 in Singapore (1302 firm-year observations), 0.061 in Thailand (1357 firm-year observations) over 1996-2002. PERSIS, which captures (the negative of) the extent to which an earnings innovation remains in the series, has a mean value of -0.44 . This value is roughly similar to values reported by Francis et al. (2004) for an average of 1,471 firms per year over 1975-2001 in the U.S. that reported a mean value of -0.482 . PREDICT has a mean value of 0.07 . As a benchmark, Boonlert-U-Thai et al. (2006) reported mean values of 0.074 in Singapore (1302 firm-year observations), and 0.074 in Thailand (1357 firm-year observations) over 1996-2002. Finally, SMOOTH, which captures the variability of income relative to the variability of cash flows, had a mean value of 0.49 . In comparison, Hunt et al. (2000) reported a mean ratio of income volatility to cash volatility of $0.51 \quad(11,976$ firm-year observations) over the 1986-1994 sample.

< Insert Table 3 about here>

As shown in Table 3, UW_DoB has a range between 0.23 and 0.49 , and W_DoB has a range of 0.23 and 0.51 . The mean value is 0.31 for both variables. This range indicates that the structure of board of directors among firms in the sample is 
with and without assigning weights to the attributes constituting diversity-of-boards. The range for UW_DiB is between zero and 7 , and its mean value is 2.91 . The range for W_DiB is between zero and 41.2 and its mean value is 16.11 . The means values of UW_DiB and W_DiB indicate that diversity-in-boards in the sample is quite low. Despite substantial efforts to privatize, the average state ownership (STATE) in the Vietnamese sample is 27.61 per cent, with the highest state ownership is 79.07 per cent.

Table 4 reports the pairwise correlation for all variables examined in this study. Four individual earnings quality measures (AQ, PERSIS, PREDICT, and SMOOTH) are highly correlated with the coefficients more than 0.3 , suggesting reasonable factorability (Hair 1998). Additionally, the KaiserMeyer-Olkin measure of sampling adequacy is 0.76 for the overall test and more than 0.7 for each earnings attribute measure (not tabulated), above the commonly recommended value of greater than 0.5 (Hair 1998). The Bartlett's test of sphericity is significant $\left(\chi^{2}(6)=257.77, \mathrm{p}<0.000\right.$ ) (not tabulated). Adopting the 'eigenvalue-greater-than one rule' (Hair 1998), this study reduces the number of factors to one because there is only one factor with eigenvalue of 2.62 (not tabulated). Factor analysis suggests that a single factor represents these four earnings attribute measures, and they accounted for 65.53 per cent of the total variance, above the 
criterion of 60 per cent (Hair 1998). Hence, it is proper to combine the four earnings attributes measures into a single standardised aggregate measure of earnings quality. This approach is similar to Leuz et al. (2003) who used factor analysis to clarify the combination of four individual earnings management measures into a standardised aggregate earnings management score.

< Insert Table 4 about here $>$

Interestingly, as shown in Table 4, UW_DoB and W_DoB are significantly and positively correlated $(\mathrm{r}=0.987)$. Similarly, UW_DiB is significantly and positively correlated with W_DiB $(r=0.986)$. These results suggest that weighted board diversity indices built based on executives' perceptions is similar to unweighted board diversity indices. Table 4 also shows that the two measures of UW_DoB and W_DoB are positively correlated with EQ as expected, while both UW_DiB and W_DiB show no significant correlations.

\section{Regression analyses}

We checked the variance inflation factor (VIF) for our regression models. The maximum VIF is 1.37 , which is less than 10 for all the regression models. Thus, the multicollinearity does not seem to be a problem for our test models (Gujarati and Porter 2009). To avoid the problem of heteroskedasticity, OLS regression with heteroskedasticity 
robust standard errors (White 1980) was used to test the relationships implicit in equations (5) and (6).

Table 5 reports the results of the regression analyses using an aggregate earnings quality score (i.e., EQ) as the dependent variable; and UW_DoB, W_DoB, UW_DiB, W_DiB alternately as the independent variables. As shown in the table, the coefficient estimate of both UW_DoB and W_DoB are positive and significant (p-values of 0.055 and 0.040 respectively). Because higher aggregate earnings quality scores imply higher earnings quality, this result suggests that diversity-of-boards improves earnings quality, confirming Hypothesis 1 (i.e. diversity-of-boards improves earnings quality). Meanwhile, both UW_DiB and W_DiB (p-values of 0.256 and 0.274 respectively) are not significantly related to EQ, which rejects Hypothesis 2 (i.e. diversity-in-boards improves earnings quality).

$<$ Insert Table 5 about here $>$

The results for control variables shown in Table 5 indicate a significant negative association between EQ and LOSS, which suggests that firms with more negative income during five years are associated with lower earnings quality, consistent with prior studies (Srinidhi et al. 2011; Wang and Yung 2011). STD.SALES and LOG.OC show positive and significant coefficients. SIZE and STD.CFO are not significant. Interestingly, the coefficients of STATEOWN are significantly 
positive with EQ, indicating that state ownership plays a significant role in inducing better earnings quality. This finding is consistent with the findings of Wang and Yung (2011), who investigated the impact of state ownership on earnings management of Chinese listed firms.

There are several possible reasons for the finding of no relationships between diversity-in-boards and earnings quality. First, as shown in previous studies (Hili and Affes 2012; Ye et al. 2010), the demographic diversity attribute (gender diversity) does not have an effect on earnings quality. Additionally, based on the resource dependence theory, demographic differences between board members within a board (diversity-in-boards) are seen as a key resource that influences the strategy-making process (Ben-Amar et al. 2013; Pfeffer and Salancik 1978). In so doing, diversity-in-boards may only indirectly influence earnings quality. In contrast, diversity-of-boards is connected to structural factors, representing recommended governance 'best practices'. Diversity-of-boards helps to ensure that managers duly represent the strategic processes agreed by the board of directors, and protect all shareholders' interests (Fama 1980; Fama and Jensen 1983). Therefore, diversity-of-boards improves earnings quality.

\section{Additional analysis and robustness tests}

\section{Nonlinearity and board diversity}


Ben-Amar et al. (2013) document a U-shaped relationship between the demographic diversity of board of directors, measured by a demographic diversity index, and merger and acquisition performance. Therefore, we added the square of UW_DoB, W_DoB, UW_DiB and W_DiB to the models in Table 5 to test whether there was a U-shaped relationship between board diversity (both diversity-of-boards and diversity-in-boards) and earnings quality.

The results reported in Table 6 indicate that diversity-ofboards indices (both unweighted and weighted) and their squared values are not statistically related to the aggregate earnings quality score. This suggests that a linear specification is adequate in capturing the relationship between diversity-ofboards and earnings quality, as far as our sample is concerned. Meanwhile, the diversity-in-boards indices (both unweighted and weighted) and their squared values are statistically significant (p-values of 0.017 and 0.040 for UW_DiB and UW_DiB ${ }^{2}$ respectively, and 0.023 and 0.043 for W_DiB and W_DiB ${ }^{2}$ respectively). The coefficients of diversity-in-boards indices (both unweighted and weighted) are negative and statistically significant; whereas the coefficients of their squared values are positive and significant, which is consistent with a U-shaped curve. These results are consistent those of Ben-Amar et al. (2013), who examined the relationship between the board of directors' diversity configurations and 
merger and acquisition performance and found that demographic diversity had a clear and non-linear effect with a U-shaped curve on merger and acquisition performance, but that statutory diversity had no statistically significant influence.

< Insert Table 6 about here>

Given the estimated values for the UW_DiB and UW_DiB ${ }^{2}$ coefficients, the turning point of the relationship between diversity-in-boards (unweighted index) and earnings quality is: ${ }^{5}$ Minimization point $=-$ coefficient of UW_DiB $/ 2 *$ coefficient of UW_DiB ${ }^{2}=-(-8.97) / 2 \times 1.18 \approx 4$.

These results suggest that as diversity-in-boards on the board of directors increases, the sample firms engage in a negative effect on earnings quality. This is probably because the benefits of demographic diversity are counterbalanced by problems related to integration difficulties (Ben-Amar et al. 2013). However, when UW_DiB is beyond 4, diversity-inboards improves the quality of earnings.

Measuring the aggregate earnings quality score excluding the accruals quality measure

Dechow and Dichev's (2002) accruals model is used as a measure of earnings attribute in the present study, but according to Wysocki (2006), Dechow and Dichev model does not comprehensively capture a firm's earnings quality. More specifically, Wysocki find that current cash flows are simultaneously significantly and negatively related to current 
accruals. Gaio and Raposo (2011) that use Dechow and Dichev accruals model also mention this issue as a limitation of their aggregate earnings quality measure. To test the validity of the results (whether the accruals quality measure using Dechow and Dichev's (2002) model significantly impacts on the standardised aggregate earnings quality score in the present study, this study measured the standardised aggregate earnings quality score by excluding the accruals quality measure. The standardised aggregate earnings quality score is computed by averaging the firm rankings for the three individual earnings quality measures (i.e., PERSIS, PREDICT, SMOOTH). The results (not tabulated) are similar to those in Tables 5 and 6 .

The impact of board diversity on individual earnings attributes

To check the robustness of the positive relationship between diversity-of-boards and earnings quality, and the non-linear relationship between diversity-in-boards and earnings quality, similar regression models as in Tables 5 and 6 , are run with replacing the standardised aggregate earnings quality score by four individual earnings attribute variables (AQ, PERSIS, PREDICT, and SMOOTH) respectively. Given almost identical results are obtained by using either unweighted or weighted index, and for brevity, this study report results using weighted indices of board diversity only. 
Panel A of Table 7 reports the results of the regression analyses using each earnings quality measure (i.e., AQ, PERSIS, PREDICT, SMOOTH) as the dependent variable and W_DoB as the independent variable. Results show that W_DoB is significantly related to all four earnings attribute measures. The coefficient estimates of W_DoB are negative and significant at the 0.10 level or better in these regressions where AQ, PERSIS, PREDICT, and SMOOTH alternately are the dependent variables. The results in Panel A of Table 7 indicate that diversity-of-boards improves earnings quality (considered individually). It is similar to the main findings from the impact of diversity-of-boards on the standardised aggregate earnings quality score.

\section{< Insert Table 7 about here>}

As reported in Panel B of Table 7, the coefficients of W_DiB were still not significant. These results, therefore confirm the initial evidence that diversity-in-boards is not related to earnings quality. Interestingly, Panel $\mathrm{C}$ of Table 7 shows that there is a non-linear relationship between diversity-in-boards and AQ as well as between diversity-in-boards and PREDICT. The coefficients of $\mathrm{W} \_\mathrm{DiB}$ are positive and statistically significant; whereas the coefficients of their quadratic terms are negative and significant. The larger the value of AQ and PREDICT, the lower the earnings quality. Therefore, the results are consistent with a U-shaped curve between diversity-in- 
boards and earnings quality, similar to the earlier finding when examining the standardised aggregate earnings quality score as a dependent variable. However, W_DiB and its quadratic terms are not significant to PERSIS and SMOOTH.

\section{Alternative regression specifications}

This paper measures diversity-in-boards indices through the terciles split method which split the sample into terciles for each demographic attribute of board of directors to rank diversity levels (Ben-Amar et al. 2013; Hafsi and Turgut 2013). For a robustness check, this thesis measured diversity-in-boards indices using median and quartile values alternately to rank firms' diversity levels. Specifically, the median split method categorized each demographic attribute into two groups, taking one if every value above the median, otherwise zero. The quartile split method categorized each demographic attribute into four groups, taking zero for the first quartile, one for the second quartile, two for the third quartile, and three for the fourth quartile. The results are similar to the main findings.

\section{Summary and concluding remarks}

This paper develops diversity-of-boards and diversity-in-boards indices (including both unweighted and weighted) and explores the relationship between board diversity and earnings quality measured by a standardised aggregate score compiled from four accounting-based measures of earnings quality of Vietnamese listed firms. We hypothesise that diversity-of-boards and 
diversity-in-boards are positively associated with earnings quality (Hypotheses 1 and 2 respectively). The results are consistent with expectations for Hypothesis 1, but not for Hypothesis 2. Specifically, our findings suggest that diversityof-boards (using both weighted and unweighted indices) improves earnings quality. The diversity-in-boards (using both weighted and unweighted indices) is not linearly related to earnings quality, and results suggest a nonlinear relationship with a U-shaped curve between diversity-in-boards and earnings quality.

We construct weighted diversity-of-boards and weighted diversity-in-boards indices to examine their influences to avoid treating attributes with equal importance when lumping attributes in diversity-of-boards and diversity-in-boards indices. There is no significant difference in the relation between board diversity and earnings quality using weighted and unweighted approaches to construct board diversity indices. We also conduct several other robustness checks to explore the robustness of our results, but our main findings and inferences are not affected.

However, we acknowledge that the sample size may limit the generalizability of our results. This is because there must be 7 years' data available to measure accruals quality, while two Vietnamese stock exchanges, HOSE and HNX, were established in the years 2000 and 2005, respectively. Future 
studies could explore a large-scale longitudinal analysis of our study.

In spite of the limitations, this study makes contributions. First, this is the first concerted attempt to examine the impact of board diversity on the quality of earnings for a small and newly emerging market, Vietnam. Vietnam is one of the lowest ranked countries for protecting investors among the Southeast Asian countries (World Bank, 2013). The findings of this study assist Vietnamese policymakers in reviewing the implications of the current corporate governance codes about boards of directors in the context of Vietnam to increase firms' reporting transparency and accountability to investors. It may also assist other emerging nations with a low level of investor protection but striving to improve corporate governance. Second, most previous studies on board diversity have focused on either demographic or structural attributes of boards of directors separately. The board diversity measure in this study uses a wide range of demographic and structural attributes to construct two different dimensions of board diversity, including diversity-of-boards and diversity-in-boards. This approach takes a broader view of board diversity impacts on earnings quality. Third, the design and development of board diversity indices (both weighted and unweighted) may help to advance ways of measuring board diversity. 
Appendix. Method of measuring unweighted diversity-ofboards index (UW_DoB)

First, we measured the dissimilarity between a given firm and another firm, and we then measured such dissimilarity for all other firms, using a mathematical distance function defined by Han and Kamber (2006) as follows:

$$
d(i, j)=\frac{\sum_{f=1}^{p} \delta_{i j}^{(f)} d_{i j}^{(f)}}{\sum_{f=1}^{p} \delta_{i j}^{(f)}}
$$

where $d(i, j)$ is a distance function (metric) used to express the (dis)similarity between two objects (firms) $\mathrm{i}$ and $\mathrm{j}$; $\mathrm{i}$ and $\mathrm{j}$ are two p-dimensional data points represented as $\left(\mathrm{x}_{\mathrm{i} 1}, \mathrm{x}_{\mathrm{i} 2}, \ldots, \mathrm{x}_{\mathrm{ip}}\right)$ and $\left(\mathrm{x}_{\mathrm{j} 1}, \mathrm{x}_{\mathrm{j} 2}, \ldots, \mathrm{x}_{\mathrm{jp}}\right)$ respectively; the indicator $\delta_{i j}^{(f)}=1$ with the assumption that attributes $f$ are equal weights to the relative contributions of each attribute $f$ to the distance function.

Then, the contribution of attribute $f$ to the dissimilarity between $\mathrm{i}$ and $\mathrm{j}$ (i.e., $d_{i j}^{(f)}$ ) is computed based on the data type of the attribute:

a) If $f$ is binary or categorical: $d_{i j}^{(f)}=0$ if $\mathrm{x}_{i f}=\mathrm{x}_{j f}$, or otherwise $d_{i j}^{(f)}=1$;

b) If $f$ is interval scale: $d_{i j}^{(f)}=\frac{\left|x_{i f}-x_{i f}\right|}{\max _{h} x_{h f}-\min _{h} x_{h f}}$ where h runs over all non-missing objects for attribute $f$;

c) If $f$ is ordinal: compute ranks $r_{i f}$ and $z_{i f}=\frac{r_{i f}-1}{M_{f}-1}$, and treat $\mathrm{z}_{i f}$ as interval-scaled $\left(r_{i f} \in\left[1, \ldots, \mathrm{M}_{f}\right]\right)$; 
d) If $f$ is ratio scale: either perform logarithmic transformation and treat the transformed data as interval scale; or treat $f$ as continuous ordinal data, compute $\mathrm{r}_{i f}$ and $\mathrm{z}_{i f}$, and then treat $\mathrm{z}_{i f}$ as interval scale; or treat ratio scale attributes like interval scale attributes.

In this function, the contribution of dissimilarity all different attributes (i.e., $d_{i j}^{(f)}$ ) are normalized, and hence expressed on a common scale of $[0,1]$. Then, we take the average distance (dissimilarity) to all the other boards (we deduct 1 because we compare a firm with other firms without the firm being compared):

$$
D(i)=\frac{\sum_{j=1}^{n} d(i, j)}{n-1}
$$

where $\mathrm{n}$ is the number of firm boards; $\mathrm{D}(\mathrm{i})$ is the average distance (dissimilarity) of firm board i to all other boards in the sample, namely UW_DoB of each firm board.

\section{References}

Adams, R. B. and Ferreira, D. 2009, 'Women in the boardroom and their impact on governance and performance', Journal of Financial Economics, 94, 2: 291-309.

Agrawal, A. and Nasser, T. 2011, 'Blockholders on boards and CEO compensation, turnover and firm valuation', Working Paper, University of Alabama.

Agrawal, A. and Nasser, T. 2012, 'Corporate Financial and Investment Policies in the Presence of a Blockholder on the 
Board', 2012 Financial Intermediation Research Society Conference, Minnesota.

Agresti, A. and Agresti, B. F. 1978, 'Statistical Analysis of Qualitative Variation', Sociological Methodology, 9: 204237.

Baysinger, B. D. and Butler, H. N. 1985, 'Corporate Governance and the Board of Directors: Performance Effects of Changes in Board Composition', Journal of Law, Economics, \& Organization, 1, 1: 101-124.

Ben-Amar, W., Francoeur, C., Hafsi, T. and Labelle, R. 2013, 'What Makes Better Boards? A Closer Look at Diversity and Ownership', British Journal of Management, 24, 1: 85101.

Blau, P. M. 1977, Inequality and heterogeneity : a primitive theory of social structure, New York, Free Press.

Boonlert-U-Thai, K., Meek, G. K. and Nabar, S. 2006, 'Earnings attributes and investor-protection: International evidence', The International Journal of Accounting, 41, 4: $327-357$.

Carlin, T. M. and Pham, C. D. 2009, 'From Public To Private: Evidence From a Transitional Economy Setting', Australian Accounting Review, 19, 3: 207-216.

Carpenter, M. A. 1998, 'Internationalization and Firm Governance: The Roles of CEO Compensation, Top Team 
Composition, and Board Structure', The Academy of Management Journal, 41, 2: 158-178.

Davis, G. F. and Cobb, J. A. 2010, 'Chapter 2: Resource dependence theory: Past and future', Research in the Sociology of Organizations, 28: 21-42.

Dechow, P. M. and Dichev, I. D. 2002, 'The Quality of Accruals and Earnings: The Role of Accrual Estimation Errors', The Accounting Review, 77: 35-59.

Demirguc-Kunt, A., Love, I. and Maksimovic, V. 2006, 'Business environment and the incorporation decision', Journal of Banking and Finance, 30, 11: 2967-2993.

Dess, G. G. and Davis, P. S. 1984, 'Porter's (1980) Generic Strategies as Determinants of Strategic Group Membership and Organizational Performance', The Academy of Management Journal, 27, 3: 467-488.

Ding, Y., Zhang, H. and Zhang, J. 2007, 'Private vs State Ownership and Earnings Management: evidence from Chinese listed companies', Corporate Governance: An International Review, 15, 2: 223-238.

Donaldson, L. and Davis, J. H. 1991, 'Stewardship Theory or Agency Theory: CEO Governance and Shareholder Returns', Australian journal of management, 16, 1: 49-64.

Erhardt, N. L., Werbel, J. D. and Shrader, C. B. 2003, 'Board of Director Diversity and Firm Financial Performance', 
Corporate Governance: An International Review, 11, 2: $102-111$

Fama, E. F. 1980, 'Agency Problems and the Theory of the Firm', The Journal of Political Economy, 88, 2: 288-307.

Fama, E. F. and Jensen, M. C. 1983, 'Separation of Ownership and Control', Journal of Law and Economics, 26, 2: 301325.

Francis, B., Hasan, I., Park, J. C. and Wu, Q. 2009, 'Gender Differences in Financial Reporting Decision-Making: Evidence from Accounting Conservatism', Contemporary Accounting Research, Forthcoming.

Francis, J., Huang, A. H., Rajgopal, S. and Zang, A. Y. 2008, 'CEO Reputation and Earnings Quality', Contemporary Accounting Research, 25, 1: 109-147.

Francis, J., LaFond, R., Olsson, P. and Schipper, K. 2005, 'The market pricing of accruals quality', Journal of Accounting and Economics, 39, 2: 295-327.

Francis, J., LaFond, R., Olsson, P. M. and Schipper, K. 2004, 'Costs of Equity and Earnings Attributes', The Accounting Review, 79, 4: 967-1010.

Gaio, C. and Raposo, C. 2011, 'Earnings quality and firm valuation: international evidence', Accounting \& Finance, 51, 2: 467-499.

Gujarati, D. N. and Porter, D. C. 2009, Basic econometrics, Boston, McGraw-Hill Irwin. 
Guthrie, J. P., Grimm, C. M. and Smith, K. G. 1991, 'Environmental Change and Management Staffing: An Empirical Study', Journal of Management, 17, 4: 735-748.

Hafsi, T. and Turgut, G. 2013, 'Boardroom Diversity and its Effect on Social Performance: Conceptualization and Empirical Evidence', Journal of Business Ethics, 112, 3: 463-479.

Hair, J. F. 1998, Multivariate data analysis, Upper Saddle River, N.J, Prentice-Hall International.

Hambrick, D. C. and Mason, P. A. 1984, 'Upper Echelons: The Organization as a Reflection of Its Top Managers', The Academy of Management Review, 9, 2: 193-206.

Han, J., Kamber, M. and Ebrary 2006, Data mining: concepts and techniques, Boston, Morgan Kaufmann.

Haniffa, R. and Hudaib, M. 2006, 'Corporate Governance Structure and Performance of Malaysian Listed Companies', Journal of Business Finance \& Accounting, 33, 7-8: 1034-1062.

Harrison, D. A. and Klein, K. J. 2007, 'What's the Difference? Diversity Constructs as Separation, Variety, or Disparity in Organizations', The Academy of Management Review, 32, 4: 1199-1228.

Hartley, J. and Betts, L. R. 2010, 'Four layouts and a finding: the effects of changes in the order of the verbal labels and 
numerical values on Likert-type scales', International Journal of Social Research Methodology, 13, 1: 17-27.

Heijltjes, M., Olie, R. and Glunk, U. 2003, 'Internationalization of Top Management Teams in Europe', European Management Journal, 21, 1: 89-97.

Hili, W. and Affes, H. 2012, 'Corporate Boards Gender Diversity and Earnings Persistence: The Case of French Listed Firms', Global Journal of Management and Business Research, 12, 22: 51-59.

Hunt, A., Moyer, S. E. and Shevlin, T. 2000, 'Earnings Volatility, Earnings Management, and Equity Value', Working paper, University of Washington.

Jackling, B. and Johl, S. 2009, 'Board structure and firm performance: evidence from India's top companies', Corporate Governance: An International Review, 17, 4: 492-509.

Jayati, S., Subrata, S. and Kaustav, S. 2008, 'Board of Directors and Opportunistic Earnings Management: Evidence from India', Journal of Accounting, Auditing \& Finance, 23, 4: $517-551$

Jensen, M. C. 1993, 'The Modern Industrial Revolution, Exit, and the Failure of Internal Control Systems', The Journal of Finance, 48, 3: 831-880. 
Jensen, M. C. and Meckling, W. H. 1976, 'Theory of the firm: Managerial behavior, agency costs and ownership structure', Journal of Financial Economics, 3, 4: 305-360.

Kang, H., Cheng, M. and Gray, S. J. 2007, 'Corporate Governance and Board Composition: diversity and independence of Australian boards', Corporate Governance: An International Review, 15, 2: 194-207.

Klein, A. 2002, 'Audit committee, board of director characteristics, and earnings management', Journal of Accounting and Economics, 33, 3: 375-400.

Labelle, R., Makni Gargouri, R. and Francoeur, C. 2010, 'Ethics, Diversity Management, and Financial Reporting Quality', Journal of Business Ethics, 93, 2: 335-353.

Leuz, C., Nanda, D. and Wysocki, P. D. 2003, 'Earnings management and investor protection: an international comparison', Journal of Financial Economics, 69, 3: 505527.

Lipe, R. 1990, 'The Relation between Stock Returns and Accounting Earnings Given Alternative Information', The Accounting Review, 65, 1: 49-71.

Mahadeo, J. D., Soobaroyen, T. and Hanuman, V. O. 2012, 'Board Composition and Financial Performance: Uncovering the Effects of Diversity in an Emerging Economy', Journal of Business Ethics, 105, 3: 375-388. 
McCabe, A. C., Ingram, R. and Dato-on, M. C. 2006, 'The Business of Ethics and Gender', Journal of Business Ethics, 64, 2: 101-116.

Milliken, F. J. and Martins, L. L. 1996, 'Searching for Common Threads: Understanding the Multiple Effects of Diversity in Organizational Groups', The Academy of Management Review, 21, 2: 402-433.

Mulili, B. M. and Wong, P. 2011, 'Corporate Governance Practices in Developing Countries: The Case for Kenya', International Journal of Business Administration, 2, 1: 1427.

Oxelheim, L., Gregoric, A., Randoy, T. and Thomsen, S. 2013, 'On the internationalization of corporate boards: The case of Nordic firms', Journal of International Business Studies 44, 3: 173-194.

Park, Y. W. and Shin, H.-H. 2004, 'Board composition and earnings management in Canada', Journal of Corporate Finance, 10, 3: 431-457.

Pfeffer, J. 1973, 'Size, Composition, and Function of Hospital Boards of Directors: A Study of Organization-Environment Linkage', Administrative Science Quarterly, 18, 3: 349364.

Pfeffer, J. and Salancik, G. R. 1978, The external control of organizations: a resource dependence perspective. New York, Harper \& Row. 
Phan, K. C. and Zhou, J. 2014, 'Market efficiency in emerging stock markets: A case study of the Vietnamese stock market', IOSR Journal of Business and Management, 16, 4: $61-73$.

Post, C., Rahman, N. and Rubow, E. 2011, 'Green Governance: Boards of Directors' Composition and Environmental Corporate Social Responsibility', Business \& Society, 50, 1: 189-223.

Prior, D., Surroca, J. and Tribó, J. A. 2008, 'Are socially responsible managers really ethical?: exploring the relationship between earnings management and corporate social responsibility', Corporate Governance: An International Review, 16, 3: 160-177.

Rahman, R. A. and Ali, F. H. M. 2006, 'Board, audit committee, culture and earnings management: Malaysian evidence', Managerial Auditing Journal, 21, 7: 783-804.

Reidenbach, R. E. and Robin, D. P. 1991, 'A Conceptual Model of Corporate Moral Development', Journal of Business Ethics, 10, 4: 273-284.

Robert, M. B., Shivaram, R. and Mohan, V. 2008, 'Accounting Discretion, Corporate Governance, and Firm Performance', Contemporary Accounting Research, 25, 2: 351-405.

Sonnenfeld, J. A. 2002, 'What makes great boards great', Harvard Business Review, 80, 9: 106. 
Srinidhi, B. I. N., Gul, F. A. and Tsui, J. 2011, 'Female directors and earnings quality', Contemporary Accounting Research, 28, 5: 1610-1644.

Truong, D. L., Ger, L. and Robert, L. 2008, 'Stock-market efficiency in thin-trading markets: the case of the Vietnamese stock market', Applied Economics, 42, 27: 3519-3532.

Van der Walt, N., Ingley, C., Shergill, G. S. and Townsend, A. 2006, 'Board configuration: are diverse boards better boards?', Corporate Governance, 6, 2: 129-147.

Vu, K. A., Tower, G. and Scully, G. 2011, 'Corporate communication for Vietnamese listed firms', Asian Review of Accounting, 19, 2: 125-146.

Wally, S. and Baum, J. R. 1994, 'Personal and Structural Determinants of the Pace of Strategic Decision Making', The Academy of Management Journal, 37, 4: 932-956.

Wang, L. and Yung, K. 2011, 'Do State Enterprises Manage Earnings More than Privately Owned Firms? The Case of China', Journal of Business Finance \& Accounting, 38, 7-8: 794-812.

White, H. 1980, 'A Heteroskedasticity-Consistent Covariance Matrix Estimator and a Direct Test for Heteroskedasticity', Econometrica, 48, 4: 817-838. 
Wysocki, P. 2006, 'Assessing earnings and accrual quality:

U.S. and international evidence', Working Paper, Massachusetts Institute of Technology.

Ye, K., Zhang, R. and Rezaee, Z. 2010, 'Does top executive gender diversity affect earnings quality? A large sample analysis of Chinese listed firms', Advances in Accounting, incorporating Advances in International Accounting, 26, 1: $47-54$ 
Table 1 Description of the variables included in diversity indices)

\begin{tabular}{|c|c|}
\hline Variables & Measurement \\
\hline \multicolumn{2}{|c|}{ Included variables in diversity-of-boards indices } \\
\hline CEO/chair separation & $\begin{array}{l}0 \text { if the chairperson also serves as the CEO } \\
\text { and } 1 \text { otherwise. }\end{array}$ \\
\hline $\begin{array}{l}\text { Non-executive directors } \\
\text { owning more than } 5 \% \text { of a } \\
\text { firm's equity } \\
\text { (blockholders) }\end{array}$ & $\begin{array}{l}1 \text { if there is more than one non-executive } \\
\text { director who also serves as a blockholder and } \\
0 \text { otherwise. }\end{array}$ \\
\hline $\begin{array}{l}\text { Representative directors' } \\
\text { ownership }\end{array}$ & $\begin{array}{l}\text { The percentage of state ownership represented } \\
\text { by directors. }\end{array}$ \\
\hline Promoters & $\begin{array}{l}\text { The number of inside directors also serves as } \\
\text { representative directors for government } \\
\text { divided by total number of directors on the } \\
\text { board of directors. }\end{array}$ \\
\hline \multicolumn{2}{|c|}{ Included variables in diversity-in-boards indices } \\
\hline Director gender & $\begin{array}{l}\text { Using modified Blau's index with a } \\
\text { classification of male and female directors }\end{array}$ \\
\hline Director age & $\begin{array}{l}\text { Using modified Blau's index with a } \\
\text { classification of five subgroupings: under } 36 \\
\text { years, } 36-45,46-55,56-65 \text {, and over } 65\end{array}$ \\
\hline Director education degree & $\begin{array}{l}\text { Using modified Blau's index with a } \\
\text { classification of four subgroupings: } \mathrm{PhD} \text {, } \\
\text { master's, bachelor's and others }\end{array}$ \\
\hline Director nationality & $\begin{array}{l}\text { Using modified Blau's index with a } \\
\text { classification of foreign and domestic } \\
\text { directors }\end{array}$ \\
\hline
\end{tabular}


Table 2 Descriptive statistics for importance rating based on industry executives' responses

\begin{tabular}{lcccc}
\hline \multicolumn{1}{c}{ Importance rating } & Max & Min & Mean & SD \\
\hline Structural attributes & & & & \\
CEO/chair serperation & 10 & 3 & 8.2 & 1.22 \\
\% Representative directors' ownership & 10 & 6 & 7.8 & 1.08 \\
\% Promoters & 10 & 6 & 8.5 & 1.19 \\
Non-executive directors owning > 5\% of a & & & & \\
firm's equity & 9 & 3 & 7.1 & 1.73 \\
\hline Demographic attributes & & & & \\
Gender diversity in board of directors & 7 & 0 & 4.3 & 2.35 \\
Age diversity in board of directors & 8 & 0 & 5.6 & 2.32 \\
Education degree diversity in board of directors & 8 & 3 & 6 & 1.36 \\
Nationality diversity in board of directors & 9 & 5 & 7.5 & 1.06 \\
\hline
\end{tabular}


Table 3. Descriptive statistics

\begin{tabular}{|c|c|c|c|c|}
\hline Variables & Max & Min & Mean & SD \\
\hline \multicolumn{5}{|l|}{$\overline{\text { Dependent variables }}$} \\
\hline EQ & 126.50 & 1.00 & 75.50 & 27.65 \\
\hline \multicolumn{5}{|c|}{ Four earnings attributes to construct the aggregate earnings quality score } \\
\hline AQ & 0.4 & 0.001 & 0.06 & 0.06 \\
\hline PERSIS & 4.78 & -2.8 & -0.44 & 0.86 \\
\hline PREDICT & 0.4 & 0.01 & 0.07 & 0.08 \\
\hline SMOOTH & 2.65 & 0.03 & 0.49 & 0.45 \\
\hline \multicolumn{5}{|l|}{ Independent variables } \\
\hline UW_DoB & 0.49 & 0.23 & 0.31 & 0.07 \\
\hline W_DoB & 0.51 & 0.23 & 0.31 & 0.07 \\
\hline UW_DiB & 7.00 & 0.00 & 2.91 & 1.69 \\
\hline W_DiB & 41.20 & 0.00 & 16.11 & 9.71 \\
\hline \multicolumn{5}{|c|}{ Structural attributes of board of directors to construct DoB_Index } \\
\hline $\mathrm{CEO} /$ chair seperation & 1 & 0 & 0.61 & 0.49 \\
\hline \% Representative directors' ownership & 0.79 & 0 & 0.22 & 0.23 \\
\hline$\%$ Promoters & 0.86 & 0 & 0.13 & 0.2 \\
\hline $\begin{array}{l}\text { Non-executive directors owning }>5 \% \text { of a } \\
\text { firm's equity }\end{array}$ & 1 & 0 & 0.14 & 0.35 \\
\hline \multicolumn{5}{|c|}{ Demographic attributes of board of directors measured by the modified } \\
\hline Gender diversity in board of directors & 0.98 & 0.00 & 0.39 & 0.38 \\
\hline Age diversity in board of directors & 0.92 & 0.00 & 0.64 & 0.20 \\
\hline $\begin{array}{l}\text { Education degree diversity in board of } \\
\text { directors }\end{array}$ & 0.93 & 0.00 & 0.38 & 0.27 \\
\hline Nationality diversity in board of directors & 1.00 & 0.00 & 0.08 & 0.23 \\
\hline \multicolumn{5}{|l|}{ Control variables } \\
\hline SIZE & 7.24 & 4.36 & 5.69 & 0.62 \\
\hline STD.CFO & 0.77 & 0.02 & 0.16 & 0.11 \\
\hline STD.SALES & 2.33 & 0.02 & 0.38 & 0.42 \\
\hline LOG.OC & 3.37 & 1.07 & 2.15 & 0.38 \\
\hline LOSS & 3 & 0 & 0.25 & 0.6 \\
\hline STATE & 1.00 & 0.00 & 0.51 & 0.50 \\
\hline
\end{tabular}

This table shows summary statistics for variables used in this paper. The final sample consists of 150 firms listed on HOSE and HNX, each with a continuous listing history over the entire period from 2005 to 2011 for the 2010 sample. EQ is the firm-specific standardised aggregate earnings quality score; AQ, PERSIS, PREDICT and SMOOTH are firm-specific accruals quality, earnings persistence, earnings predictability and earnings smoothness values, respectively; UW_DoB and W_DoB are unweighted and weighted diversity-of-boards indices respectively; UW_DiB and W_DiB are unweighted and weighted diversity-in-boards indices respectively; SIZE is firm size; STD.CFO is cash flow variability; STD.SALES is sales variability; LOG.OC is length of operating cycle; LOSS is the firm's incidence of net loss realizations; STATE is state ownership. 
Table 4 Correlation matrix

\begin{tabular}{|c|c|c|c|c|c|c|c|c|c|c|c|c|c|c|c|}
\hline & 1 & 2 & 3 & 4 & 5 & 6 & 7 & 8 & 9 & 10 & 11 & 12 & 13 & 14 & 15 \\
\hline $1 \mathrm{AQ}$ & 1.000 & & & & & & & & & & & & & & \\
\hline 2 PERSIS & 0.394 & 1.000 & & & & & & & & & & & & & \\
\hline 3 PREDICT & 0.666 & 0.390 & 1.000 & & & & & & & & & & & & \\
\hline 4 SMOOTH & 0.618 & 0.317 & 0.771 & 1.000 & & & & & & & & & & & \\
\hline $5 \quad$ EQ & -0.520 & -0.422 & -0.585 & -0.566 & 1.000 & & & & & & & & & & \\
\hline 6 UW_DoB & -0.120 & -0.160 & -0.144 & -0.191 & 0.151 & 1.000 & & & & & & & & & \\
\hline 7 W_DoB & -0.123 & -0.176 & -0.156 & -0.194 & 0.167 & 0.987 & 1.000 & & & & & & & & \\
\hline 8 UW_DiB & 0.120 & -0.013 & 0.044 & -0.010 & -0.134 & -0.058 & -0.100 & 1.000 & & & & & & & \\
\hline 9 W_DiB & 0.113 & -0.018 & 0.036 & -0.014 & -0.132 & -0.069 & -0.110 & 0.986 & 1.000 & & & & & & \\
\hline 10 SIZE & 0.028 & -0.075 & 0.044 & -0.028 & -0.002 & 0.160 & 0.194 & 0.147 & 0.193 & 1.000 & & & & & \\
\hline 11 STD.CFO & 0.112 & 0.060 & 0.169 & -0.200 & 0.003 & -0.038 & -0.032 & -0.019 & -0.026 & -0.064 & 1.000 & & & & \\
\hline 12 STD.SALES & 0.009 & -0.060 & -0.033 & -0.141 & 0.026 & -0.136 & -0.128 & 0.026 & 0.024 & -0.025 & 0.278 & 1.000 & & & \\
\hline 13 OPCYCLE & -0.187 & -0.140 & -0.102 & -0.063 & 0.224 & 0.011 & -0.012 & 0.118 & 0.115 & 0.108 & -0.164 & -0.439 & 1.000 & & \\
\hline 14 LOSS & -0.020 & 0.034 & 0.130 & 0.039 & -0.200 & -0.113 & -0.117 & 0.115 & 0.103 & 0.017 & 0.022 & -0.040 & -0.033 & 1.000 & \\
\hline 15 STATE & -0.148 & 0.001 & -0.221 & -0.161 & 0.164 & 0.027 & 0.109 & -0.390 & -0.403 & -0.087 & 0.039 & -0.040 & -0.125 & -0.130 & 1.000 \\
\hline
\end{tabular}

*Bold text indicates significance at the $10 \%$ level or better. 
Table 5 Board diversity (unweighted and weighted indices) and earnings quality

\begin{tabular}{|c|c|c|c|c|}
\hline Dependent Variable & EQ & EQ & EQ & EQ \\
\hline UW_DoB & $\begin{array}{l}59.67 * \\
(0.055)\end{array}$ & & & \\
\hline W_DoB & & $\begin{array}{c}67.77 * * \\
(0.040)\end{array}$ & & \\
\hline UW_DiB & & & $\begin{array}{c}-1.63 \\
(0.256)\end{array}$ & \\
\hline W_DiB & & & & $\begin{array}{c}-0.28 \\
(0.274)\end{array}$ \\
\hline SIZE & $\begin{array}{c}-1.76 \\
(0.603)\end{array}$ & $\begin{array}{l}-2.174 \\
(0.521)\end{array}$ & $\begin{array}{c}-0.08 \\
(0.981)\end{array}$ & $\begin{array}{c}0.10 \\
(0.978)\end{array}$ \\
\hline STD.CFO & $\begin{array}{c}0.82 \\
(0.966)\end{array}$ & $\begin{array}{c}0.72 \\
(0.970)\end{array}$ & $\begin{array}{c}1.18 \\
(0.951)\end{array}$ & $\begin{array}{c}1.11 \\
(0.954)\end{array}$ \\
\hline STD.SALES & $\begin{array}{c}12.77 * * \\
(0.019)\end{array}$ & $\begin{array}{c}12.831 * * \\
(0.018)\end{array}$ & $\begin{array}{c}11.27 * * \\
(0.033)\end{array}$ & $\begin{array}{l}11.20 * * \\
(0.034)\end{array}$ \\
\hline LOG.OC & $\begin{array}{c}24.20 * * * \\
(0.000)\end{array}$ & $\begin{array}{c}24.45 * * * \\
(0.000)\end{array}$ & $\begin{array}{c}23.84 * * * \\
(0.000)\end{array}$ & $\begin{array}{c}23.72 * * * \\
(0.000)\end{array}$ \\
\hline LOSS & $\begin{array}{l}-6.37 * \\
(0.083)\end{array}$ & $\begin{array}{l}-6.351 * \\
(0.082)\end{array}$ & $\begin{array}{l}-6.95^{*} \\
(0.051)\end{array}$ & $\begin{array}{c}-7.03 * * \\
(0.048)\end{array}$ \\
\hline STATE & $\begin{array}{c}23.48 * * \\
(0.015)\end{array}$ & $\begin{array}{c}21.67 * * \\
(0.024)\end{array}$ & $\begin{array}{l}19.15^{*} \\
(0.081)\end{array}$ & $\begin{array}{l}19.12 * \\
(0.086)\end{array}$ \\
\hline Constant & $\begin{array}{c}5.22 \\
(0.839)\end{array}$ & $\begin{array}{c}4.963 \\
(0.846)\end{array}$ & $\begin{array}{c}21.54 \\
(0.383)\end{array}$ & $\begin{array}{c}20.52 \\
(0.407)\end{array}$ \\
\hline Adjusted $\mathrm{R}^{2}$ & 0.120 & 0.123 & 0.104 & 0.103 \\
\hline F statistic & $4.02 * * *$ & $4.10 * * *$ & $4.11 * * *$ & $4.08 * * *$ \\
\hline p-value & 0.001 & 0.000 & 0.000 & 0.000 \\
\hline Mean VIF & 1.14 & 1.15 & 1.18 & 1.18 \\
\hline
\end{tabular}

The p-values are in parentheses, calculated using standard errors corrected for heteroskedasticity. Statistical significance is indicated by ***,**, and * for $1 \%, 5 \%$, and $10 \%$. 
Table 6 Nonlinear relationship between board diversity and earnings quality

\begin{tabular}{|c|c|c|c|c|}
\hline & EQ & EQ & EQ & EQ \\
\hline UW_DoB & $\begin{array}{l}172.65 \\
(0.558)\end{array}$ & & & \\
\hline UW_DoB ${ }^{2}$ & $\begin{array}{c}-164.72 \\
(0.699)\end{array}$ & & & \\
\hline W_DoB & & $\begin{array}{c}1.26 \\
(0.997)\end{array}$ & & \\
\hline W_DoB ${ }^{2}$ & & $\begin{array}{c}98.36 \\
(0.818)\end{array}$ & & \\
\hline UW_DiB & & & $\begin{array}{c}-8.97 * * \\
(0.017)\end{array}$ & \\
\hline UW_DiB ${ }^{2}$ & & & $\begin{array}{l}1.18^{* *} \\
(0.040)\end{array}$ & \\
\hline W_DiB & & & & $\begin{array}{c}-1.44 * * \\
(0.023)\end{array}$ \\
\hline W_DiB ${ }^{2}$ & & & & $\begin{array}{l}0.03 * * \\
(0.043)\end{array}$ \\
\hline SIZE & $\begin{array}{c}-1.75 \\
(0.606)\end{array}$ & $\begin{array}{c}-2.29 \\
(0.505)\end{array}$ & $\begin{array}{c}-0.18 \\
(0.960)\end{array}$ & $\begin{array}{c}-0.06 \\
(0.987)\end{array}$ \\
\hline STD.CFO & $\begin{array}{c}0.91 \\
(0.962)\end{array}$ & $\begin{array}{c}0.64 \\
(0.973)\end{array}$ & $\begin{array}{c}4.71 \\
(0.807)\end{array}$ & $\begin{array}{c}4.46 \\
(0.817)\end{array}$ \\
\hline STD.SALES & $\begin{array}{c}12.64 * * \\
(0.020)\end{array}$ & $\begin{array}{c}12.90 * * \\
(0.017)\end{array}$ & $\begin{array}{c}11.39 * * \\
(0.033)\end{array}$ & $\begin{array}{c}11.05^{* *} \\
(0.038)\end{array}$ \\
\hline LOG.OC & $\begin{array}{c}24.23 * * * \\
(0.000)\end{array}$ & $\begin{array}{c}24.50 * * * \\
(0.000)\end{array}$ & $\begin{array}{c}23.55^{* * *} \\
(0.000)\end{array}$ & $\begin{array}{c}23.55 * * * \\
(0.000)\end{array}$ \\
\hline LOSS & $\begin{array}{l}-6.42 * \\
(0.084)\end{array}$ & $\begin{array}{l}-6.34^{*} \\
(0.081)\end{array}$ & $\begin{array}{l}-6.82 * \\
(0.059)\end{array}$ & $\begin{array}{l}-6.78^{*} \\
(0.061)\end{array}$ \\
\hline STATE & $\begin{array}{c}22.73 * * \\
(0.018)\end{array}$ & $\begin{array}{c}21.67 * * \\
(0.024)\end{array}$ & $\begin{array}{c}19.06 * \\
(0.080)\end{array}$ & $\begin{array}{c}19.33 * \\
(0.080)\end{array}$ \\
\hline Constant & $\begin{array}{l}-12.96 \\
(0.819)\end{array}$ & $\begin{array}{c}16.19 \\
(0.782)\end{array}$ & $\begin{array}{c}30.13 \\
(0.224)\end{array}$ & $\begin{array}{c}28.22 \\
(0.258)\end{array}$ \\
\hline Adjusted $\mathrm{R}^{2}$ & 0.115 & 0.117 & 0.119 & 0.115 \\
\hline F statistic & $3.50 * * *$ & $3.80 * * *$ & $4.18 * * *$ & $4.06 * * *$ \\
\hline $\mathrm{p}$-value & 0.001 & 0.001 & 0.000 & 0.000 \\
\hline
\end{tabular}


Table 7 Board diversity and individual earnings attribute measures

\begin{tabular}{|c|c|c|c|c|c|c|c|c|c|c|c|c|}
\hline & \multicolumn{4}{|c|}{ Panel A: Diversity-of-boards and individual EQ measures } & \multicolumn{4}{|c|}{ Panel B: Diversity-in-boards and individual EQ measures } & \multicolumn{4}{|c|}{ Panel C: Nonlinearity and diversity-in-boards } \\
\hline & $\mathrm{AQ}$ & PERSIS & PREDICT & SMOOTH & $\mathrm{AQ}$ & PERSIS & PREDICT & SMOOTH & $\mathrm{AQ}$ & PERSIS & PREDICT & SMOOTH \\
\hline W_DoB & $\begin{array}{l}-0.133^{*} \\
(0.077)\end{array}$ & $\begin{array}{c}-2.463 * * \\
(0.020)\end{array}$ & $\begin{array}{c}-0.173 * * \\
(0.032)\end{array}$ & $\begin{array}{c}-1.473 * * * \\
(0.001)\end{array}$ & & & & & & & & \\
\hline W_DiB & & & & & $\begin{array}{c}0.001 \\
(0.230)\end{array}$ & $\begin{array}{c}0.001 \\
(0.933)\end{array}$ & $\begin{array}{l}-0.001 \\
(0.367)\end{array}$ & $\begin{array}{l}-0.003 \\
(0.416)\end{array}$ & $\begin{array}{c}0.0034 * * \\
(0.023)\end{array}$ & $\begin{array}{l}-0.0160 \\
(0.505)\end{array}$ & $\begin{array}{c}0.0034 * \\
(0.093)\end{array}$ & $\begin{array}{l}0.0102 \\
(0.481)\end{array}$ \\
\hline W_DiB ${ }^{2}$ & & & & & & & & & $\begin{array}{c}-0.0001 * \\
(0.093)\end{array}$ & $\begin{array}{l}0.0005 \\
(0.462)\end{array}$ & $\begin{array}{c}-0.0001 * * \\
(0.039)\end{array}$ & $\begin{array}{l}-0.0004 \\
(0.263)\end{array}$ \\
\hline SIZE & $\begin{array}{c}0.010 \\
(0.186)\end{array}$ & $\begin{array}{l}-0.020 \\
(0.864)\end{array}$ & $\begin{array}{c}0.014 \\
(0.215)\end{array}$ & $\begin{array}{c}0.006 \\
(0.927)\end{array}$ & $\begin{array}{c}0.004 \\
(0.609)\end{array}$ & $\begin{array}{l}-0.080 \\
(0.467)\end{array}$ & $\begin{array}{c}0.010 \\
(0.372)\end{array}$ & $\begin{array}{l}-0.021 \\
(0.729)\end{array}$ & $\begin{array}{l}0.0047 \\
(0.579)\end{array}$ & $\begin{array}{l}-0.0822 \\
(0.486)\end{array}$ & $\begin{array}{l}0.0106 \\
(0.340)\end{array}$ & $\begin{array}{l}-0.0194 \\
(0.751)\end{array}$ \\
\hline STD.CFO & $\begin{array}{c}0.059 \\
(0.155)\end{array}$ & $\begin{array}{c}0.559 \\
(0.379)\end{array}$ & $\begin{array}{c}0.137 * * \\
(0.046)\end{array}$ & $\begin{array}{c}-1.083^{* * *} \\
(0.000)\end{array}$ & $\begin{array}{c}0.092 \\
(0.203)\end{array}$ & $\begin{array}{c}0.541 \\
(0.327)\end{array}$ & $\begin{array}{l}0.183 * \\
(0.068)\end{array}$ & $\begin{array}{c}-1.096 * * * \\
(0.001)\end{array}$ & $\begin{array}{l}0.0841 \\
(0.228)\end{array}$ & $\begin{array}{l}0.5891 \\
(0.366)\end{array}$ & $\begin{array}{c}0.1709 * \\
(0.078)\end{array}$ & $\begin{array}{c}-1.1348 * * * \\
(0.000)\end{array}$ \\
\hline STD.SALES & $\begin{array}{l}-0.022 \\
(0.110)\end{array}$ & $\begin{array}{c}-0.423 * * \\
(0.032)\end{array}$ & $\begin{array}{c}-0.030 * * \\
(0.049)\end{array}$ & $\begin{array}{c}-0.217 * * \\
(0.012)\end{array}$ & $\begin{array}{l}-0.032 \\
(0.182)\end{array}$ & $\begin{array}{l}-0.353 \\
(0.116)\end{array}$ & $\begin{array}{l}-0.042 \\
(0.144)\end{array}$ & $\begin{array}{c}-0.171 * * \\
(0.040)\end{array}$ & $\begin{array}{l}-0.0314 \\
(0.183)\end{array}$ & $\begin{array}{c}-0.3550 * \\
(0.073)\end{array}$ & $\begin{array}{l}-0.0419 \\
(0.145)\end{array}$ & $\begin{array}{c}-0.1695 * * \\
(0.043)\end{array}$ \\
\hline LOG.OC & $\begin{array}{c}-0.048 * * * \\
(0.003)\end{array}$ & $\begin{array}{c}-0.504 * * \\
(0.017)\end{array}$ & $\begin{array}{c}-0.033^{*} \\
(0.078)\end{array}$ & $\begin{array}{c}-0.231 * * \\
(0.022)\end{array}$ & $\begin{array}{c}-0.061 * * \\
(0.022)\end{array}$ & $\begin{array}{c}-0.460 * \\
(0.059)\end{array}$ & $\begin{array}{l}-0.048 \\
(0.143)\end{array}$ & $\begin{array}{c}-0.197 * \\
(0.046)\end{array}$ & $\begin{array}{c}-0.0611 * * \\
(0.022)\end{array}$ & $\begin{array}{c}-0.4623 * * \\
(0.032)\end{array}$ & $\begin{array}{l}-0.0476 \\
(0.144)\end{array}$ & $\begin{array}{c}-0.1951^{* *} \\
(0.049)\end{array}$ \\
\hline LOSS & $\begin{array}{l}-0.007 \\
(0.375)\end{array}$ & $\begin{array}{l}-0.013 \\
(0.914)\end{array}$ & $\begin{array}{l}0.017 * \\
(0.058)\end{array}$ & $\begin{array}{c}0.009 \\
(0.856)\end{array}$ & $\begin{array}{l}-0.010 \\
(0.313)\end{array}$ & $\begin{array}{c}0.021 \\
(0.821)\end{array}$ & $\begin{array}{c}0.015 \\
(0.215)\end{array}$ & $\begin{array}{c}0.032 \\
(0.483)\end{array}$ & $\begin{array}{l}-0.0103 \\
(0.295)\end{array}$ & $\begin{array}{l}0.0243 \\
(0.839)\end{array}$ & $\begin{array}{l}0.0137 \\
(0.254)\end{array}$ & $\begin{array}{l}0.0295 \\
(0.528)\end{array}$ \\
\hline STATE & $\begin{array}{c}-0.050 * * \\
(0.041)\end{array}$ & $\begin{array}{l}-0.071 \\
(0.827)\end{array}$ & $\begin{array}{c}-0.079 * * * \\
(0.009)\end{array}$ & $\begin{array}{l}-0.305^{*} \\
(0.052)\end{array}$ & $\begin{array}{l}-0.064 \\
(0.191)\end{array}$ & $\begin{array}{l}-0.132 \\
(0.746)\end{array}$ & $\begin{array}{c}-0.128 * * \\
(0.040)\end{array}$ & $\begin{array}{c}-0.404 * * \\
(0.034)\end{array}$ & $\begin{array}{l}-0.0649 \\
(0.189)\end{array}$ & $\begin{array}{l}-0.1293 \\
(0.717)\end{array}$ & $\begin{array}{c}-0.1286^{* *} \\
(0.039)\end{array}$ & $\begin{array}{c}-0.4061 * * \\
(0.033)\end{array}$ \\
\hline
\end{tabular}




\begin{tabular}{|c|c|c|c|c|c|c|c|c|c|c|c|c|}
\hline Constant & $\begin{array}{c}0.160 * * \\
(0.031)\end{array}$ & $\begin{array}{l}1.616^{*} \\
(0.055)\end{array}$ & $\begin{array}{c}0.120 \\
(0.104)\end{array}$ & $\begin{array}{c}1.742 * * * \\
(0.000)\end{array}$ & $\begin{array}{l}0.176^{*} \\
(0.075)\end{array}$ & $\begin{array}{c}1.072 \\
(0.240)\end{array}$ & $\begin{array}{c}0.150 \\
(0.213)\end{array}$ & $\begin{array}{c}1.425 * * * \\
(0.001)\end{array}$ & $\begin{array}{c}0.1583 * \\
(0.086)\end{array}$ & $\begin{array}{l}1.1816 \\
(0.159)\end{array}$ & $\begin{array}{l}0.1232 \\
(0.281)\end{array}$ & $\begin{array}{c}1.3345 * * * \\
(0.004)\end{array}$ \\
\hline Adjusted $\mathrm{R}^{2}$ & 0.055 & 0.038 & 0.127 & 0.153 & 0.055 & 0.000 & 0.083 & 0.108 & 0.058 & -0.003 & 0.093 & 0.111 \\
\hline F statistic & $2.37 * *$ & $1.84^{*}$ & $4.56 * * *$ & $6.50 * * *$ & $2.37 * *$ & 1.01 & 3.47 *** & $4.92 * * *$ & $2.08 * *$ & 0.95 & $2.90 * * *$ & $4.46 * * *$ \\
\hline $\mathrm{p}$-value & 0.025 & 0.084 & 0.000 & 0.000 & 0.025 & 0.430 & 0.002 & 0.000 & 0.041 & 0.481 & 0.005 & 0.000 \\
\hline
\end{tabular}

The $\mathrm{p}$-values are in parentheses. Statistical significance is indicated by ***,**, and * for $1 \%, 5 \%$, and $10 \%$.

${ }^{1}$ In the Vietnamese listed firms, the concept of outside and inside directors has not been clarified and practiced yet. Presently, just only non-executive directors are defined as outside/independent directors and executive directors are considered inside directors.

${ }^{2}$ Gaio and Raposo (2011) used a 6-year rolling windows instead of a 14-year rolling windows to compute earnings quality measures and reported similar results.

3 For validity purposes, this study also used four individual earnings attribute measures (accruals quality, earnings persistence, earnings predictability and earnings smoothness) instead of the standardised aggregate earnings quality score in the robustness tests.

${ }^{4}$ The survey was carried out in accordance with Ethical Requirements for Research with Low Risk, and this study has been approved by the Human Research Ethics Committee.

${ }^{5}$ Because almost identical results are obtained by using either unweighted or weighted index, for brevity, this paper only presents results using unweighted index of diversityin-boards. Other results are available upon request. 